\title{
Immunization with Amyloid- $\beta$ Attenuates Inclusion Body Myositis-Like Myopathology and Motor Impairment in a Transgenic Mouse Model
}

\author{
Masashi Kitazawa, ${ }^{1,3}$ Vitaly Vasilevko, ${ }^{3}$ David H. Cribbs, ${ }^{2,3}$ and Frank M. LaFerla ${ }^{1,3}$ \\ Departments of ${ }^{1}$ Neurobiology and Behavior and ${ }^{2}$ Neurology, and ${ }^{3}$ Institute for Brain Aging and Dementia, University of California, Irvine, Irvine, \\ California 92697-4545
}

Inclusion body myositis (IBM), the most common muscle disease to afflict the elderly, causes slow but progressive degeneration of skeletal muscle and ultimately paralysis. Hallmark pathological features include T-cell mediated inflammatory infiltrates and aberrant accumulations of proteins, including amyloid- $\beta(\mathrm{A} \beta)$, tau, ubiquitinated-proteins, apolipoprotein E, and $\alpha$-synuclein in skeletal muscle. A large body of work indicates that aberrant $\mathrm{A} \beta$ accumulation contributes to the myodegeneration. Here, we investigated whether active immunization to promote clearance of $A \beta$ from affected skeletal muscle fibers mitigates the IBM-like myopathological features as well as motor impairment in a transgenic mouse model. We report that active immunization markedly reduces intracellular $A \beta$ deposits and attenuates the motor impairment compared with untreated mice. Results from our current study indicate that $A \beta$ oligomers contribute to the myopathy process as they were significantly reduced in the affected skeletal muscle from immunized mice. In addition, the anti-A $\beta$ antibodies produced in the immunized mice blocked the toxicity of the $\mathrm{A} \beta$ oligomers in vitro, providing a possible key mechanism for the functional recovery. These findings provide support for the hypothesis that $\mathrm{A} \beta$ is one of the key pathogenic components in IBM pathology and subsequent skeletal muscle degeneration.

\section{Introduction}

Prominent amyloid- $\beta(\mathrm{A} \beta)$ accumulation and the presence of inclusion bodies are pathological hallmarks of several neurological disorders, including Alzheimer disease (AD) and inclusion body myositis (IBM). IBM, the most common skeletal muscle disorder to afflict the elderly, is clinically characterized by proximal and distal skeletal muscle degeneration and accompanied by marked inflammatory infiltration (Dalakas, 2006b). The etiology for the vast majority of IBM cases remains unknown, and no effective treatment has yet been established. Approximately $5-10 \%$ cases are hereditary and can be caused by mutations in several genes, including the myosin heavy chain II, UDP-Nacetylglucosamine-2-epimerase/ $N$-acetylmannosamine kinase (GNE) or in valosin-containing protein (VCP) (Martinsson et al., 2000; Eisenberg et al., 2001; Kayashima et al., 2002; Watts et al., 2004; Askanas and Engel, 2005; Dalakas, 2006a).

IBM-affected skeletal muscle exhibits several distinct myopathological features, which include the accumulation of protein aggregates such as $\mathrm{A} \beta$, hyperphosphorylated tau, and poly-

Received March 9, 2009; accepted April 8, 2009.

This study was supported by grants from the National Institutes of Health (NIH): NIH/National Institute on Aging (NIA) R01AG20335 (F.M.L.), R01AG20241 (D.H.C.), and P01AG00538 (D.H.C), and NIH-National Institute of Arthritis and Musculoskeletal and Skin Diseases K99AR054695 (M.K.). A $\beta$ peptides and antibodies were provided by the University of California, Irvine Alzheimer's Disease Research Center funded by NIH-NIA Grant P50AG16573 and the Institute for Brain Aging and Dementia funded by the NIH Program Project Grant AG00538.

Correspondence should be addressed to Dr. Frank M. LaFerla, Department of Neurobiology and Behavior, 1109 Gillespie Neuroscience Facility, University of California, Irvine, Irvine, CA 92697-4545. E-mail: laferla@uci.edu. DOI:10.1523/JNEUROSCI.1150-09.2009

Copyright $\odot 2009$ Society for Neuroscience $\quad$ 0270-6474/09/296132-10\$15.00/0 ubiquitinated proteins (Askanas et al., 1991, 1993, 1994; Fidziañska and Glinka, 2006). These protein aggregates are more commonly associated with $\mathrm{AD}$, where $\mathrm{A} \beta$ is considered to play a central pathogenic role in the neurodegenerative process. In IBM, however, the role of $\mathrm{A} \beta$ is still unresolved, but a large body of studies indicates that $\mathrm{A} \beta$ may contribute to the muscle degeneration (McFerrin et al., 1998; Querfurth et al., 2001; Wojcik et al., 2006). Moreover, it is well documented that expression of amyloid precursor protein (APP) is significantly elevated, and most notably that $\mathrm{A} \beta_{42}$ preferentially accumulates in affected muscle fibers of IBM patients (Sarkozi et al., 1993; Vattemi et al., 2003; Askanas and Engel, 2008).

Because aberrant accumulation of $\mathrm{A} \beta$ appears to play a role in IBM, we generated several mouse models that overexpress human APP or that selectively overproduce $A \beta_{1-42}$. These models develop key pathological and behavioral features of IBM in an age-dependent manner, including selective accumulation of $\mathrm{A} \beta$ in muscle fibers and myopathological features, including increased $\mathrm{CD} 8{ }^{+}$T-cell infiltrates and hyperphosphorylated tau, as well as impaired motor function. Our previous work provides in vivo evidence that $\mathrm{A} \beta$ plays a significant role in the development of IBM-like myopathology, in agreement with other reports (Fukuchi et al., 1998; Jin et al., 1998; Moussa et al., 2006).

In the present study, we sought to determine whether the sustained presence of $A \beta$ is necessary to maintain impaired motor function in this mouse model. In other words, once $\mathrm{A} \beta$ initiated motor impairment occurs, is $A \beta$ still required or will its clearance rescue motor function and/or slow the rate of decline? Accordingly, we actively immunized mice against $\mathrm{A} \beta$ and found 
that it markedly attenuated the motor impairment. Moreover, the reduction in insoluble $\mathrm{A} \beta$ in skeletal muscle and plasma $\mathrm{A} \beta$ levels correlated with the restoration of motor performance. Notably, active immunization reduced oligomeric and fibrillar forms of $\mathrm{A} \beta$ in skeletal muscle. To elucidate which $\mathrm{A} \beta$ assembly state adversely affects myotubes, we performed in vitro studies and found that that $\mathrm{A} \beta$ oligomers were more toxic to differentiated murine myotubes than fibrillar $\mathrm{A} \beta$. Anti-A $\beta$ antibodies isolated from immunized mice significantly blocked the cytotoxicity of $\mathrm{A} \beta$ oligomers, highlighting the potent pathological effects these oligomers exert on skeletal muscle, which is comparable to effects observed with neurons.

\section{Materials and Methods}

Animals and immunization protocol. Twelve-month-old MCK-APP/PS1 mice (20 males and 19 females) were used in this study (Kitazawa et al., 2006). Mice were divided into three groups: untreated ( 5 males and 5 females), sham-treated ( 7 males and 6 females), and actively immunized ( 8 males and 8 females).

A $\beta_{1-33}$-MAP peptide was synthesized on a four-branched poly-lysine core (Invitrogen) and used as an antigenic peptide. For the active immunization, $100 \mu \mathrm{g}$ of $\mathrm{A} \beta_{1-33}$-MAP peptide mixed with complete Freund's adjuvant (CFA; Sigma-Aldrich) was used for the initial injection with subsequent injections using incomplete Freund's adjuvant (IFA) in total volume of $100 \mu \mathrm{l}$ adjusted with PBS. The sham-treated group received injections of adjuvant only. The vaccine was delivered intraperitoneally with a 2 week interval before the first boost, and monthly thereafter. Mice received a total of five injections. Blood was collected before the first immunization (prebleed) and $10 \mathrm{~d}$ after each boost from the retro-orbital sinus into the EDTA-coated tubes. Tubes were centrifuged for $10 \mathrm{~min}$ at $4^{\circ} \mathrm{C}$, and the plasma were collected as a supernatant and stored at $-80^{\circ} \mathrm{C}$ for the further analysis.

Detection of cytokines production by ELISPOT. Presence and type of A $\beta$ specific T-cells was analyzed by ELISPOT assay (Cribbs et al., 2003). Production of proinflammatory lymphokine IFN- $\gamma$ (Th1) or antiinflammatory IL-4 (Th2) was evaluated by restimulation of splenocytes from experimental mice. Briefly, 96-well ELISPOT plates (BD PharMingen) were coated with capture IFN- $\gamma$ or IL- 4 specific antibodies. Splenocytes from individual animals were added in tetraplicate wells $\left(2 \times 10^{5}\right.$ cells/well) and were restimulated with $5 \mu \mathrm{M} \mathrm{A} \beta_{1-33}$-MAP peptide, $5 \mu \mathrm{M}$ $\mathrm{A} \beta_{1-40}$ peptide, or left without restimulation in a culture medium only. After incubation for $36 \mathrm{~h}\left(37^{\circ} \mathrm{C}, 5 \% \mathrm{CO}_{2}\right)$, cytokines were detected with biotinylated detection antibodies, followed by avidin-HRP. Substrate AEC (Sigma-Aldrich) was added to develop the reaction. Spots representing cytokine-producing cells were counted using dissecting microscope (Olympus) by three independent investigators. Averaged data are presented as number of cytokine secreting cells per $1 \times 10^{6}$ splenocytes without restimulation or after restimulation with peptides $\mathrm{A} \beta_{1-33}$-MAP or $\mathrm{A} \beta_{1-40}$.

A $\beta$ oligomers and fibrils preparation. $\mathrm{A} \beta_{42}$ peptide was kindly provided by Dr. C. Glabe (University of California, Irvine Alzheimer's Disease Research Center, Irvine, CA). A $\beta$ oligomers or fibrils enriched preparations were made according to previously published method (Kayed et al., 2003, 2007). Briefly, fibrils were prepared in $10 \mathrm{~mm}$ Tris pH 7.4 buffer. The samples were stirred with a Teflon-coated micro stir bar at $500 \mathrm{rpm}$ at room temperature for $6 \mathrm{~d}$. Fibril formation was monitored by thioflavin $\mathrm{T}$ fluorescence. Once fibril formation was complete, the solutions were centrifuged at $14,000 \times g$ for $20 \mathrm{~min}$, the fibril pellet was washed $3 \times$ with the doubly distilled water, and then resuspended in the PBS, pH7.4 buffer. The final peptide concentration was $0.3-0.5 \mathrm{mg} / \mathrm{ml}$.

Soluble oligomers were prepared by dissolving $1.0 \mathrm{mg}$ of $\mathrm{A} \beta_{42}$ in 400 $\mu \mathrm{l}$ of hexafluoroisopropanol (HFIP) for 10-20 min at room temperature. The resulting seedless $\mathrm{A} \beta$ solution $(100 \mu \mathrm{l})$ was added to $900 \mu \mathrm{l}$ of distilled, deionized $\mathrm{H}_{2} \mathrm{O}$ in a siliconized tube. After 10-20 min incubation at room temperature, the samples were centrifuged for $15 \mathrm{~min}$ at $14,000 \times g$, and the supernatant fraction was transferred to a new siliconized tube and subjected to a gentle stream of $\mathrm{N}_{2}$ for 5-10 min to evaporate the HFIP. The samples were then stirred at $500 \mathrm{rpm}$ using a
Teflon-coated micro stir bar for $24-48 \mathrm{~h}$ at $22^{\circ} \mathrm{C}$. The oligomer formation was assessed by dot blot described below.

Cell culture and viability assays. C2C12 myoblasts from $\mathrm{C} 3 \mathrm{H}$ mouse strain (ATCC) were maintained in DMEM containing 10\% fetal bovine serum (FBS), 50 units penicillin and $50 \mu \mathrm{g} / \mathrm{ml}$ streptomycin at $37^{\circ} \mathrm{C}$ in a humidified atmosphere containing $5 \% \mathrm{CO}_{2}$. Cells were plated in 96-well plate at a concentration of 5000 cells/well for 24 h. For differentiating $\mathrm{C} 2 \mathrm{C} 12$ cells, culture media were replaced with differentiation media (DMEM with 2\% FBS and penicillin/streptomycin) and further incubated for $5 \mathrm{~d}$. Differentiation of $\mathrm{C} 2 \mathrm{C} 12$ was confirmed by immunofluorescent staining with muscle creatine kinase (Santa Cruz Biotechnology), fast-type skeletal myosin heavy chain, or MyoD1 (both from Abcam) with TOTO3 nuclear counter stain. Undifferentiated or differentiated $\mathrm{C} 2 \mathrm{C} 12$ cells were exposed to oligomeric or fibrillar $\mathrm{A} \beta$ at a concentrating ranging from 0.01 to $10 \mu \mathrm{M}$ in DMEM containing $1 \%$ FBS for additional $24 \mathrm{~h}$. For studies involving neutralization with antibodies, $30 \mu \mathrm{g} / \mathrm{ml} \mathrm{pu-}$ rified antibody from immunized mice, 20.1 antibody (Oddo et al., 2006 b), or preimmune mouse IgG was added together with oligomeric $\mathrm{A} \beta$. Cytotoxicity was assessed by lactate dehydrogenase (LDH) assay kit (Sigma-Aldrich).

Immunohistochemical analysis. Skeletal muscle tissue was snap frozen in liquid nitrogen-cooled isopentane and stored at $-80^{\circ} \mathrm{C}$. Cryosections were cut at $10 \mu \mathrm{m}$, placed onto silane-coated slides, and stored at $-20^{\circ} \mathrm{C}$. Hematoxylin-and-eosin ( $\mathrm{HE}$ ) staining and Gomori trichrome staining were performed to determine the general morphology of the muscle. Serial sections were used to identify oligomeric and amyloid deposits by A11 antibody, OC antibody (generous gift from Dr. C. Glabe), 6E10biotinylated antibody (Signet Laboratories), and specific antibody for $\mathrm{x}-\mathrm{A} \beta_{40}$ or $\mathrm{x}-\mathrm{A} \beta_{42}$ (generated at Institute for Brain Aging and Dementia by D.H.C. and V.V.). A11 antibody recognizes amyloidogenic soluble prefibrillar oligomer species, and OC antibody recognizes $\mathrm{A} \beta$ fibrillar oligomers that are distinct from random coil monomers or prefibrillar oligomers (Kayed et al., 2003, 2007). All double immunofluorescent images were taken and analyzed by $z$-stack confocal microscopic system (Bio-Rad 2000).

Immunoblot analysis. Skeletal muscle tissue was homogenized in T-PER buffer (Pierce) in the presence of protease inhibitor cocktail (Roche Applied Science) and phosphatase inhibitors (5 mm sodium fluoride and $1 \mathrm{~mm}$ sodium orthovanadate). The detergent-soluble fraction was isolated by centrifugation at $100,000 \times g$ for $1 \mathrm{~h}$ at $4^{\circ} \mathrm{C}$. The resultant pellet was homogenized in $70 \%$ formic acid followed by centrifugation at $100,000 \times g$ for $1 \mathrm{~h}$ at $4^{\circ} \mathrm{C}$ to isolate the detergentinsoluble fraction. Equal amounts of protein from each fraction $(\sim 50$ $\mu \mathrm{g})$ were resolved by SDS-PAGE $(4-12 \%$ Bis-Tris gel from Invitrogen). Primary antibodies used in this study were 6E10 antibody (Pierce) for full-length APP and anti- $\alpha$ B-crystallin antibody (Affinity Bioreagents). Membranes were stripped using stripping buffer (GenoTechnology) and reprobed with GAPDH (Santa Cruz Biotechnology) to control for protein loading.

Immunoprecipitation. Skeletal muscle homogenates $(150 \mu \mathrm{g})$ were incubated with $2 \mu \mathrm{g}$ of $\mathrm{A} 11$ or $6 \mathrm{E} 10$ antibody overnight at $4^{\circ} \mathrm{C}$ with gentle rocking. Protein A-agarose (for A11) or protein G-agarose (for 6E10) was added and further incubated for $2 \mathrm{~h}$. Protein-antibody complex was isolated by serial centrifugation and washing, and subsequently analyzed by immunoblotting.

Dot blot analysis. T-PER extracted skeletal muscle samples $(5 \mu \mathrm{g})$ were placed onto the nitrocellulose membrane and air-dried for $20 \mathrm{~min}$. The membrane was then blocked with 5\% fat-free milk for $2 \mathrm{~h}$ and incubated with primary antibody, A11 antibody (1:2000) or OC antibody (1:2000), overnight at $4^{\circ} \mathrm{C}$. Signals were detected by secondary anti-rabbit-HRP conjugated antibody and Supersignal Pico detection reagent (Pierce).

ELISA A $\beta$ measurement. Both detergent-soluble and -insoluble fractions were used to detect $\mathrm{A} \beta_{40}$ and $\mathrm{A} \beta_{42}$ by ELISA as described previously (Sugarman et al., 2002; Kitazawa et al., 2006).

Anti-A $\beta$ antibody ELISA. The titers of anti-A $\beta$ antibodies were measured as previously described with minor modifications (Cribbs et al., 2003). Briefly, wells of 96-well plates (Immulon 2HB, Dynatech Laboratories) were coated with $2.5 \mu \mathrm{M} \mathrm{A} \beta_{42}$ in carbonate coating buffer, $\mathrm{pH} 9.6$ (Sigma-Aldrich) and incubated overnight at $4^{\circ} \mathrm{C}$. The wells were washed, 
A

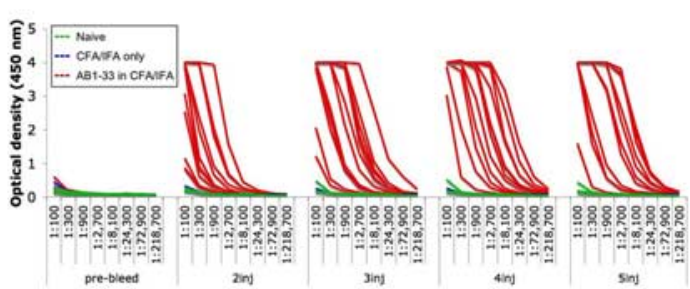

Table 1. Anti-Aß antibody plasma concentration during the course of immunization with $A B_{1,33}-M A P$

\begin{tabular}{|l|c|c|c|c|}
\hline & 2 injections & 3 injections & 4 injections & 5 injections \\
\hline $\begin{array}{l}\text { Concentration }(\mu \mathrm{g} / \mathrm{ml} \\
\text { of plasma) }\end{array}$ & 1.41 & 11.87 & 28.87 & 15.89 \\
\hline
\end{tabular}

B

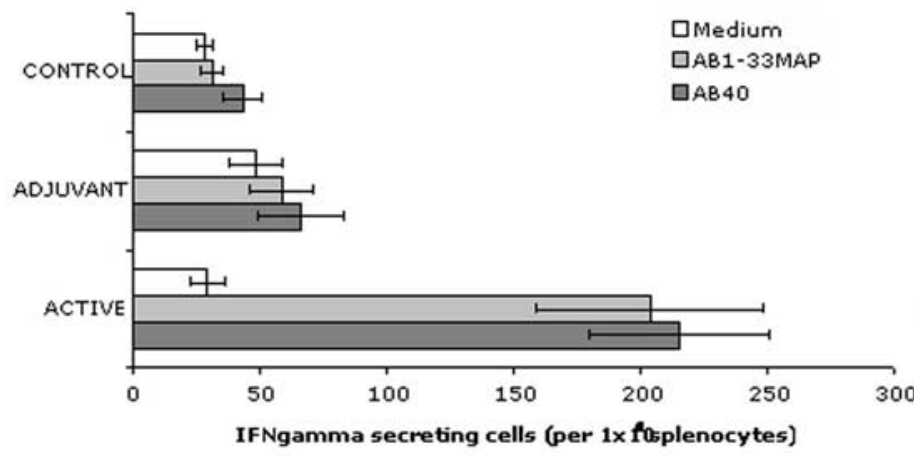

Splenocytes restimulation

CONTROL

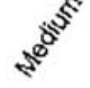

ADJUVANT
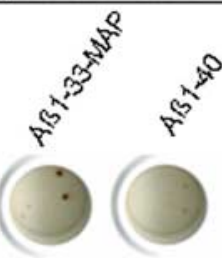

ACTIVE
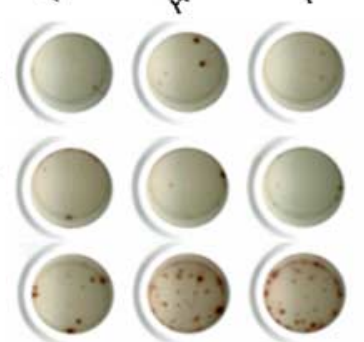

Figure 1. Antigen $A \beta_{1-33}-M A P$ induces a robust antibody response. $A$, Antibody titers against $A \beta$ were measured after each injection. Detectable anti-A $\beta$ antibody titers were induced after the second immunization with $A \beta_{1-33}$ MAP and reached the peak after the fourth injection. Each line represents the titers for an individual mouse. $B$, IFN- $\gamma$ (Th1) cytokine in splenocytes from mice after active immunization was detected after restimulation with $A \beta_{1-33} M A P$ or $A \beta_{1-40}$ peptide. Colored spots were counted after $36 \mathrm{~h}$ of restimulation. Results are shown as mean number of spots $/ 10^{6}$ cells \pm SEM. Representative picture of the ELISPOT wells with restimulated splenocytes is shown in the right panel.

and blocked with $3 \%$ nonfat dry milk for $1 \mathrm{~h}$ at $37^{\circ} \mathrm{C}$ with shaking. After washing, serial dilutions of plasma from experimental and control mice were added to the wells and the plate was incubated for $1 \mathrm{~h}$ at $37^{\circ} \mathrm{C}$ with shaking. After washing, HRP-conjugated anti-mouse $\operatorname{IgG}(\mathrm{H}+\mathrm{L})$ antibodies (Santa Cruz Biotechnology) were added at 1:4000 dilution. After incubation for $1 \mathrm{~h}$ at $37^{\circ} \mathrm{C}$ with shaking, wells were washed, and UltraTMB ELISA substrate (Pierce) was added to develop the reaction for 15 min, then $2 \mathrm{~N} \mathrm{H}_{2} \mathrm{SO}_{4}$ was added to the wells to stop the reaction, and the plates were analyzed on a Synergy HT Spectrophotometer (Bio-Tek) at $450 \mathrm{~nm}$. Concentration of the antibodies was calculated using $6 \mathrm{E} 10 \mathrm{an}-$ tibody as a standard on a KC4 Software (Bio-Tek). Isotypes of anti-A $\beta$ antibodies were detected using mouse antibody isotyping kit (Invitrogen) according to manufacture instructions. To detect IgG2 $\mathrm{a}^{\mathrm{b}}$ isotypes, we used biotinylated anti-IgG2a ${ }^{\mathrm{b}}$ antibodies (BD Bioscience) followed by streptavidin-HRP.

Rotarod motor test. Motor performance was evaluated using the accelerating rotarod (Accuscan Instruments) as described previously (Sugarman et al., 2002). Mice were placed on a rotating dowel and required to continuously walk forward to avoid falling off. For measuring balance and coordination, the rod was accelerated over $20 \mathrm{~s}$ to a constant speed of $15 \mathrm{rpm}$, and each trial was ended at $90 \mathrm{~s}$. Mice were given 10 training trials per day for 2 consecutive days, and probe trials were completed on the third day. In the probe trial, each mouse was tested 5 times and time of fall-off was recorded. For the accelerating rotarod, the rod constantly accelerated at a rate of $1 \mathrm{rpm} / \mathrm{s}$. Mice were tested for 10 trials, and the time of fall-off was recorded.

Statistical analysis. All data were analyzed using one-way ANOVA with appropriate post tests, and $p<0.05$ or lower was considered to be statistically significant.

\section{Results}

Profile of $A \boldsymbol{\beta}$ antibody response in immunized mice

In this study, we used 12-month-old MCK-APP/PS1 mice. $M C K$ APP/PS1 mice selectively overexpress human APP ( $\sim 2-4$-fold over the endogenous mouse counterpart) and accumulate $\mathrm{A} \beta_{42}$ in affected muscle fibers, both of which are important features observed in IBM patients (Sarkozi et al., 1993; Vattemi et al., 2003; Askanas and Engel, 2008). Hence, although not a complete model, these mice nevertheless, represent a useful tool for studying the pathogenic role of APP and $A \beta$ on skeletal muscle.

At 12 months, the MCK-APP/PS1 mice start to develop myopathological features as well as motor impairment, which become exacerbated in an age-dependent manner (Kitazawa et al., 2006). Hence, we sought to investigate whether the sustained presence of $A \beta$ was required for the progression of the pathological phenotype. We actively immunized mice against $A \beta$ to determine whether it would mitigate the disease phenotype. Initial studies revealed that immunizing the $M C K-A P P / P S 1$ transgenic mice with full-length fibrillar $A \beta_{1-42}$ peptide formulated in QuilA or CFA/IFA adjuvant did not produce a detectable anti-A $\beta$ antibody response after three injections, probably because of selftolerance. Also, it is worth mentioning that C57BL/6 mice are generally a poor antibody responder strain to most antigens and biased toward a Th1 (cellular) type of immune response (Reiner and Locksley, 1995; Gustavsson et al., 1998; Mills et al., 2000) (our unpublished observations). Consequently, we used a modified immunogen, $\mathrm{A} \beta_{1-33}$-MAP peptide, which demonstrated a 


\section{Constant speed}

a pre-immunized

2 months of immunization

3 months of immunization
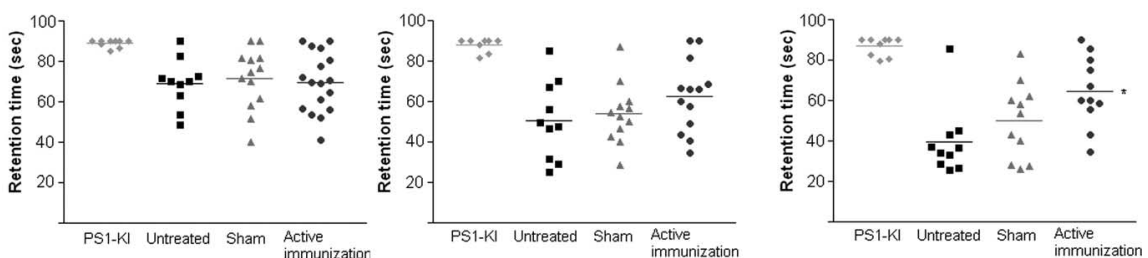

\section{Constant acceleration}

d pre-immunized

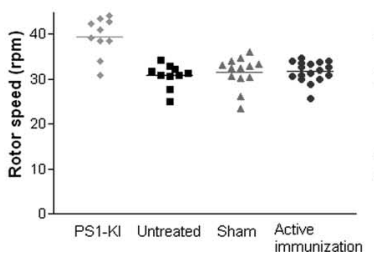

e $\quad 2$ months of immunization

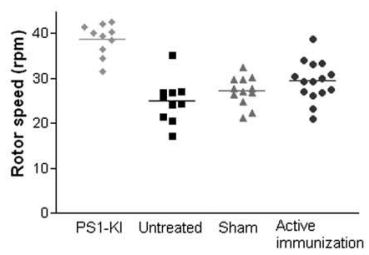

f 3 months of immunization

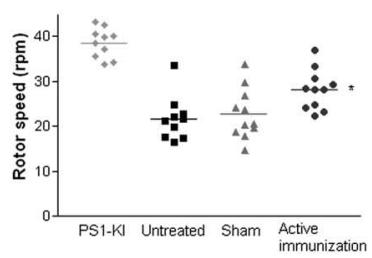

Figure 2. Actively immunized MCK-APP/PS1 mice maintain their motor function. $\boldsymbol{a}-\boldsymbol{f}$, Motor function was examined by using the rotarod with constant speed $(\boldsymbol{a}-\boldsymbol{c})$ or with constant acceleration $(\boldsymbol{d}-\boldsymbol{f})$. All mice were tested before the treatment started ( $\boldsymbol{a}$, $\boldsymbol{d}$ ), after three injections ( 2 months after the initial injection; $\boldsymbol{b}, \boldsymbol{e}$ ), and after five injections ( 3 months after the initial injection; $\boldsymbol{c}$, f). Each dot represents an individual mouse, and the line represents the mean. ${ }^{*} p<0.05$ compared with untreated group.

higher potency for inducing an antibody response compared with the traditional AN1792 formulation. The new antigen was clearly advantageous, as after two injections, anti-A $\beta$ antibodies were detectable in the actively immunized group, which mainly comprised the IgM isotype (Fig. 1A). Subsequent injections significantly augmented antibody production, and we observed antibody class switching from IgM to IgG, which indicates induction of an $A \beta$-specific T-cell response. The ratio of the IgG/IgM antibody isotype after the second injection was 1:1. At the end of the trial, however, the IgG/IgM ratio was $3: 1$, consistent with the development of T-cell dependent type of immune response. No detectable anti-A $\beta$ antibody response was observed in untreated or sham-treated animals.

The $\mathrm{A} \beta$-specific $\mathrm{T}$-cell response after active immunization was further analyzed by ELISPOT. After 5 injections, only actively immunized animals produced $\mathrm{T}$ cells specific to both peptide immunogen $\mathrm{A} \beta_{1-33}$-MAP and $\mathrm{A} \beta_{1-40}$ peptide. Both of the peptides contain a functional T-cell epitope, which is located in the region $\mathrm{A} \beta_{16-30}$ in $\mathrm{C} 57 \mathrm{BL} / 6$ mice (Monsonego et al., 2006). Not surprisingly, we detected a dominant Th1-type of the response with the splenocytes secreting proinflammatory cytokine IFN- $\gamma$ (Fig. $1 B$ ) after restimulation with $\mathrm{A} \beta_{1-33}$-MAP (204 \pm 45 cells) or $\mathrm{A} \beta_{1-40}(215 \pm 35$ cells $)$ peptides, whereas nonstimulated splenocytes have significantly lower number of IFN- $\gamma$ secreting cells ( $29 \pm 7$ cells). Splenocytes from naive and adjuvant only groups did not respond for the in vitro restimulation with the $\mathrm{A} \beta_{1-33^{-}}$ MAP or $\mathrm{A} \beta_{1-40}$ peptides (Fig. $1 B$ ). Moreover, we did not detect splenocytes secreting anti-inflammatory cytokine IL-4 (data not shown), which suggests a pronounced Th1-type of the immune response typical in C57BL/6 mice (Reiner and Locksley, 1995; Mills et al., 2000).

\section{Immunization attenuates the motor impairment}

To access the phenotypic efficacy of $A \beta$ immunotherapy, we used both the constant speed and accelerating version of the rotarod and evaluated the overall motor performance of each group of mice longitudinally. The constant speed task examines motor coordination and balance, whereas the accelerating version primarily evaluates muscle strength and duration (Boehm et al., 2000; Rustay et al., 2003). The first test was done before immunization, and no differences were observed among the three groups (Fig. 2a,d). At this age, all groups reached at average $69-71 \mathrm{~s}$ at 15 rpm constant rotation. Most of the agematched parental PS1-KI mice (MCK$A P P$ negative) stayed on the rotor for $90 \mathrm{~s}$ throughout the experimental period (Fig. 2 ). Thus, based on these studies, we determined that the MCK-APP/PS1 mice exhibited impaired motor function before the immunization therapy was initiated. After three injections of the immunogen ( 2 months after the initial injection), motor function was again assessed, and we found that the $\mathrm{A} \beta$-immunized group performed better than the untreated or shamtreated groups, although the difference was not statistically significant (Fig. 2b,e). After five injections (i.e., 3 months after the initial injection), the disparity in performance among the groups was more robust, and $\mathrm{A} \beta$-immunized group exhibited significantly better motor function than the untreated group (Fig. $2 c, f$ ). Interestingly, the sham-treated group showed a trend toward improvement compared with untreated group although it was not statistically significant, suggesting the activation of nonspecific immune responses may contribute to attenuating pathological phenotypes as previously reported (Frenkel et al., 2005). Hence, our findings indicate that the impairment of motor function was markedly slowed in the actively immunized mice, whereas motor function grew progressively worse in the control groups. The continuous decline in motor performance in the control or sham-treated groups during the experimental period suggested that the effect of learning the task in this longitudinal study was minimal (supplemental Fig. 1, available at www.jneurosci.org as supplemental material).

\section{Immunization reduces the $\mathrm{A} \boldsymbol{\beta}$ load in skeletal muscle}

We next determined whether the improved motor function in the transgenic mice was associated with an attenuation of the IBMlike myopathologies. Intramuscular vacuoles are a signature feature of IBM, and histological examination of muscle by hematoxylin-and-eosin (HE) staining revealed that vacuoles (arrowheads) were markedly reduced in muscle fibers from the actively immunized mice (Fig. 3a). At least 20 sections from each mouse were stained with $\mathrm{HE}$, and the extent of vacuoles formed in the skeletal muscle fibers were quantitatively analyzed and found significantly less in the actively immunized group (Fig. 3a). However, it should be noted that these vacuoles were different from rimmed vacuoles observed in human cases, but rather were similar to linear basophilic vacuole-like structures previously described as rimmed-cracks in another mouse model of myopathy (Weihl et al., 2007).

Other histopathological markers such as $\alpha \mathrm{B}$-crystallin and major histocompatibility complex (MHC) class I are elevated in 
IBM, hence we determined whether levels of these markers were affected by immunization on our mouse model. $\alpha \mathrm{B}$-crystallin is a small heat-shock protein that is abnormally localized and upregulated in skeletal muscle fibers of IBM patients as an indication of cellular stress (Banwell and Engel, 2000; Wojcik et al., 2006). Likewise, MHC class I molecules are also upregulated in muscle fibers, which may be responsible for the infiltration of T-cells (Ferrer et al., 2004). In the untreated or sham-treated $M C K-A P P / P S 1$ mice, $\alpha \mathrm{B}$-crystallin was found to be upregulated, whereas their levels were significantly reduced in the immunized mice, suggesting that the reduction of intracellular $\mathrm{A} \beta$ achieved by immunization significantly suppressed cellular stress responses (supplemental Fig. $2 a$, available at www.jneurosci.org as supplemental material). Conversely, there was no disparity in MHC class I levels among the three groups (supplemental Fig. $2 b$, available at www.jneurosci.org as supplemental material).

$\mathrm{A} \beta$ levels in skeletal muscle were quantitatively measured by ELISA. Although soluble $\mathrm{A} \beta_{40}$ or $\mathrm{A} \beta_{42}$ was not altered by immunization, insoluble $A \beta$ levels, particularly $\mathrm{A} \beta_{42}$, were significantly reduced in the actively immunized group (Fig. $3 c$ ). The steady-state levels of APP or APP processing in skeletal muscle were unaffected by the treatments (Fig. 3b) (data not shown). In addition, there was a good correlation between the reduction of $A \beta$ levels and antibody titers in individual mice (Fig. $3 d$ ); both insoluble $\mathrm{A} \beta_{40}$ and $\mathrm{A} \beta_{42}$ showed a linear correlation with the antibody titer with a correlation coefficient of 0.48 and 0.49 , respectively. Similarly, free A $\beta$ levels in plasma were also decreased in the immunized mice with higher anti-A $\beta$ antibody titers (supplemental Fig. 3, available at www.jneurosci.org as supplemental material). Our data suggest that the antibody generated by the active immunization effectively sequestered $A \beta$ in the plasma and lowered free plasma $\mathrm{A} \beta$, which is consistent with previous findings of passive immunization on a mouse model of $\mathrm{AD}$ (DeMattos et al., 2001).

We next addressed the mechanism by which active immunization led to the clearance of $A \beta$ in skeletal muscle fibers. It has recently been reported that antibodies are capable of being internalized and facilitating the clearance of the intracellular protein aggregates in a model of Parkinson's disease (Masliah et al., 2005). To determine whether a similar mechanism participated in the reduction of $A \beta$ in skeletal muscle after immunization, we double labeled skeletal muscle sections with anti-mouse IgG and an antibody called A11, which detects oligomeric $\mathrm{A} \beta$ species (Kayed et al., 2003). In the immunized mice, we obtained evidence showing that some muscle fibers clearly contained antibodies that were detected by anti-mouse IgG, and these antibodies were in the vicinity of A11-positive deposits (Fig. 4). Notably,

c
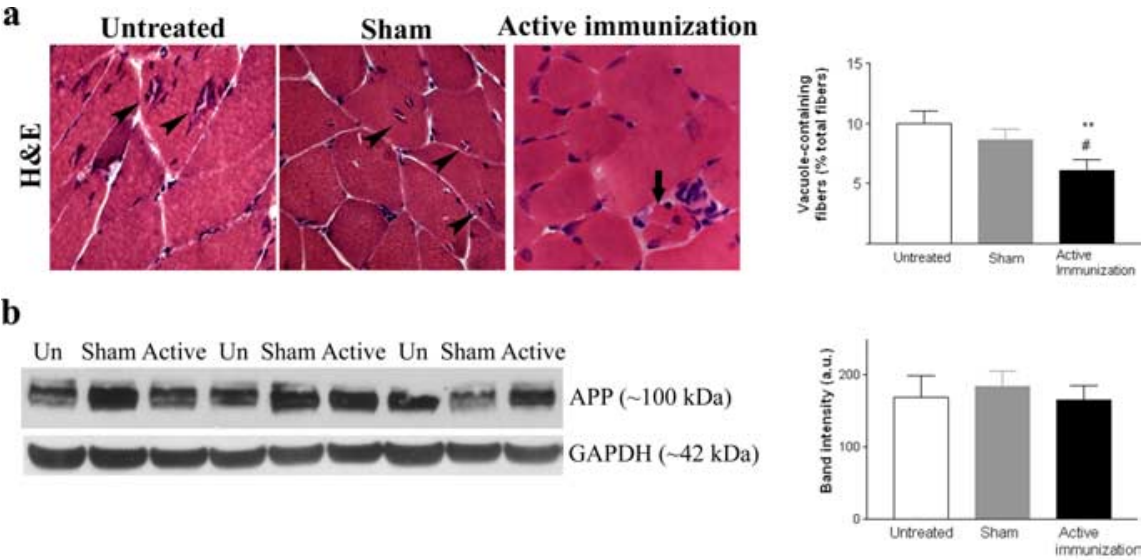

Figure 3. Active immunization attenuates skeletal muscle pathology and $A \beta$ levels. $\boldsymbol{a}$, Hematoxylin-eosin staining of skeletal muscle from untreated, sham, or immunized mice. Arrowheads indicate representative vacuole-like rimmed cracks observed in ${ }^{*} p<0.05$ compared with untreated group ( $n=10$ or more). $\boldsymbol{d}$, Correlation between plasma $A \beta$ antibody levels and $A \beta$ levels in skeletal muscle. Both insoluble $A \beta_{40}$ and insoluble $A \beta_{42}$ have significant linear correlation with plasma anti-A $\beta$ antibody levels, and their correlation coefficients are 0.48 and 0.49 , respectively.

in untreated mice, we did not find any evidence of mouse antibodies in the fibers harboring A11-positive deposits (Fig. 4). Similarly, mouse IgG surrounded $\mathrm{A} \beta_{40^{-}}$and $\mathrm{A} \beta_{42}$-immunoreactive deposits in actively immunized mice but not in untreated or sham-treated mice, further confirming the high affinity of antibodies to $\mathrm{A} \beta$ deposits (Fig. 4). Therefore, this analysis revealed that some of the mouse endogenous antibodies were able to penetrate within the skeletal muscle fibers. Based on these data, we suggest that some portion of antibody is able to enter the muscle fibers and directly bind to the amyloid deposits and mediate its degradation and clearance.

\section{A $\boldsymbol{\beta}$ oligomers in muscle}

Recent evidence from in vitro and in vivo studies indicates that $\mathrm{A} \beta$ oligomers play a crucial role in mediating neuronal toxicity and subsequent neuronal dysfunction (Walsh et al., 2002b; Lesné et al., 2006; Malaplate-Armand et al., 2006; Oddo et al., 2006a). Hence, we examined the levels of $\mathrm{A} \beta$ oligomers in the muscle 

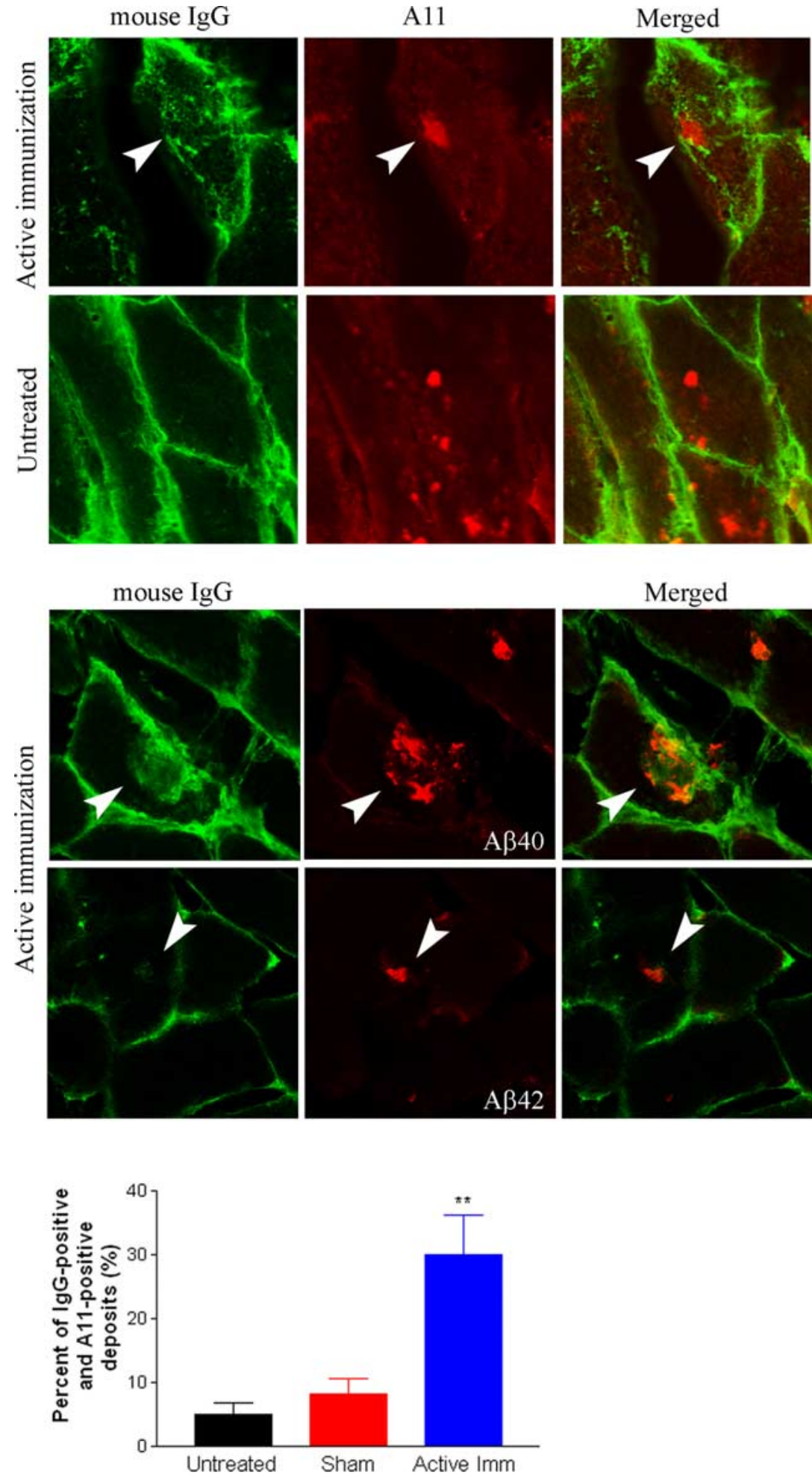

Figure 4. Mouse lgG localizes around $A \beta$ oligomer deposits in skeletal muscle fibers from actively immunized mice. Skeletal muscle sections were double immunostained with anti-mouse lgG antibody (green) and $A 11, A \beta_{40}$ or $A \beta_{42}$ specific antibody (red). The amyloid-positive deposits in actively immunized mice were surrounded or colocalized with mouse lgG, suggesting antibody-mediated $A \beta$ clearance (arrowheads). Conversely, no mouse lgG was found in the vicinity of A11-positive deposits in untreated mice. The percentage of mouse lgG-positive and A11-positive deposits were counted and expressed as percentage of total deposits in selected field as shown in the graph. ${ }^{* *} p<0.01$ compared with untreated and sham-treated groups $(n=10)$.

fibers and evaluated whether active immunization reduced their levels. To quantify $A \beta$ oligomers, we used a dot blot assay with two oligomer-specific antibodies, A11 and OC, which detect amyloidogenic prefibrillar oligomers and fibrillar $\mathrm{A} \beta$ oligomers, respectively (Kayed et al., 2003, 2007). In the immunized mice, we observed a significant reduction in the A11 signal in the dot blots compared with the untreated and sham groups $(p<0.05)$ (Fig. 5a). Likewise, the biochemical analysis also indicated that the OC-positive species were also significantly reduced in the immunized versus control groups (Fig. $5 a$ ). Finally, we immunohistochemically labeled muscle sections with antibodies A11 and OC from mice that underwent the various treatments and found that active immunization markedly reduced intracellular oligomers in skeletal muscle (Fig. 5b). Double immunofluorescent staining of skeletal muscle with antibodies 6E10 and A11 showed an overlap in staining, indicating that some immunoreactive deposits contained $\mathrm{A} \beta$ oligomers (supplemental Fig. $5 a$, available at www.jneurosci.org as supplemental material). A few amyloid deposits that were not A11-positive were also found in skeletal muscle (supplemental Fig. $4 a$, available at www.jneurosci.org as supplemental material). Furthermore, immunoprecipitation and immunoblot analysis also demonstrated that A11- or OCpositive oligomers were $\mathrm{A} \beta$ (supplemental Fig. $4 b$, available at www.jneurosci.org as supplemental material). Therefore, immunotherapy was not only able to reduce $\mathrm{A} \beta$ levels in skeletal muscle, but more importantly, it was able to significantly reduce $A \beta$ oligomers, which are generally considered to be the most cytotoxic assembly state of $A \beta$ (Walsh et al., 2002a).

\section{$A \beta$ oligomers are more cytotoxic than fibrillar A $\boldsymbol{\beta}$ to myoblast cells} Relatively little is known about the pathophysiological role of $A \beta$ oligomers in muscle cells. Hence, we used both undifferentiated and differentiated murine myoblast $\mathrm{C} 2 \mathrm{C} 12$ cells to assess cytotoxicity of oligomeric $\mathrm{A} \beta$ species using the $\mathrm{LDH}$ assay. The differentiation of $\mathrm{C} 2 \mathrm{C} 12$ cells was confirmed by the expression of muscle creatine kinase, myosin heavy chain and MyoD1, as well as the presence of multinucleated cells (Fig. 6e). Two solutions containing predominantly $\mathrm{A} \beta$ oligomers or $\mathrm{A} \beta$ fibrils were prepared (supplemental Fig. $5 a$, available at www.jneurosci.org as supplemental material). We found that $\mathrm{A} \beta$ oligomers induced cytotoxicity in both undifferentiated and differentiated $\mathrm{C} 2 \mathrm{C} 12$ cells in a dose-dependent manner after $24 \mathrm{~h}$ of exposure (Fig. $6 a, c$; supplemental Fig. $5 b, c$, available at www.jneurosci.org as supplemental material). Our studies also indicated that $A \beta$ oligomers were more toxic than fibrillar $\mathrm{A} \beta$ even at low concentrations in these cells.

Because anti-A $\beta$ antibodies provided therapeutic benefit in 
mice, we sought to determine whether the oligomer-induced cytotoxicity could be neutralized by using antibodies isolated from the actively immunized mice. Undifferentiated $\mathrm{C} 2 \mathrm{C} 12$ cells were exposed to various doses of $\mathrm{A} \beta$ oligomers for $24 \mathrm{~h}$ either in the presence or absence of affinity purified antibodies (30 $\mu \mathrm{g} / \mathrm{ml}$ ) isolated from the immunized animals. Notably, we found that sera harvested from the actively immunized mice and affinity purified on an $\mathrm{A} \beta_{1-15}$ column was able to significantly block the oligomer-mediated toxicity (Fig. 6b; supplemental Fig. 5b, available at www. jneurosci.org as supplemental material). As a positive control, we also found that mouse monoclonal N-terminal specific anti-A $\beta$ antibody [20.1 antibody (Oddo et al., 2006b)] also effectively blocked toxicity (data not shown). In contrast, the protective effect was not attributable to nonspecific cotreatment with IgG because mouse monoclonal IgG failed to block oligomer cytotoxicity (Fig. 6b). Likewise, the toxicity of $\mathrm{A} \beta$ oligomers was significantly neutralized by cotreatment with an anti-A $\beta$ antibody (20.1) in differentiated $\mathrm{C} 2 \mathrm{C} 12$ cells (Fig. 6d). These in vitro findings demonstrate that $\mathrm{A} \beta$ oligomers are potent toxic mediators that may play a key role in the progression of the muscle degeneration in a mouse model of IBM. Our in vivo studies suggest anti-A $\beta$ antibodies generated by active immunization can neutralize oligomer toxicity in muscle.

\section{Discussion}

In this study, we determined whether the sustained presence of $\mathrm{A} \beta$ in skeletal muscle is required to maintain motor dysfunction in the $M C K-A P P / P S 1$ transgenic mice. We actively immunized against $\mathrm{A} \beta$, which successfully reduced $\mathrm{A} \beta$ levels and accumulation of insoluble forms in skeletal muscle. We found the immunogen consisting of $\mathrm{A} \beta_{1-33}$ peptide linked to a lysine backbone effectively elicited an immune response and generated $\mathrm{A} \beta$ specific antibodies as early as after the second injection. After 3 months of immunization, insoluble $\mathrm{A} \beta$ levels were significantly reduced in the skeletal muscle, as were histopathological features such as vacuoles and $\alpha \mathrm{B}$-crystallin. The motor performance of the immunized mice was markedly better as determined by the constant speed and accelerating rotarod tests. These results provide strong evidence that reducing $\mathrm{A} \beta$ levels in muscle can mitigate the motor impairments.

Notably, our study also shows that active immunization lowers $A \beta$ oligomers in skeletal muscle. $A \beta$ oligomers are believed to play a critical role in the pathogenesis of $\mathrm{AD}$ and are more neurotoxic than monomers or fibrils (Caughey and Lansbury, 2003; Gong et al., 2003; Demuro et al., 2005). In addition, A $\beta$ oligomers are detected in muscle fibers from sporadic IBM patients, and these oligomers interact with $\alpha \mathrm{B}$-crystallin to potentially induce cellular stress and subsequent degenerative mechanisms (Wojcik et al., 2006). In agreement with these reports, we show that $\mathrm{A} \beta$ oligomers are highly toxic to both undifferentiated and differentiated C2C12 myoblast cells, and the cytotoxicity is effectively blocked by cotreatment with anti-A $\beta$ antibodies collected from the immunized mice. These results suggest that $\mathrm{A} \beta$ oligomers may be key mediators of toxicity in skeletal muscle.

Although numerous in vitro, in vivo, and clinical studies point to a toxic role for $\mathrm{A} \beta$ in muscle, its role in the pathogenesis of IBM remains poorly understood. Some investigators argue that IBM is a combined proteinopathy and inflammatory disease, and these two processes can interact and influence each other (Dalakas, 2006b; Needham and Mastaglia, 2008). Recent findings showing that inflammation mediates $\mathrm{A} \beta$ or tau pathology in skeletal muscle supports this view (Kitazawa et al., 2008; Schmidt et al., 2008). However, others suggest $\mathrm{A} \beta$ accumulation is a downstream event, because all known genetic mutations for the hereditary form of IBM are not associated with APP processing or degradation. Interestingly, recent mouse models of hereditary IBM harboring GNE or VCP mutations exhibit intracellular A $\beta$-like deposits in the skeletal muscle (Malicdan et al., 2007; Weihl et al., 2007), indicating that although these mutations do not have a direct relationship with APP, they modulate APP processing or $\mathrm{A} \beta$ degradation, causing the accumulation of $\mathrm{A} \beta$ in affected skeletal muscle fibers. It is important, however, to note that mouse endogenous $\mathrm{A} \beta$ does not aggregate as readily as human $\mathrm{A} \beta$, and differs by three amino acids at position 5,10 , and 13 ; several 

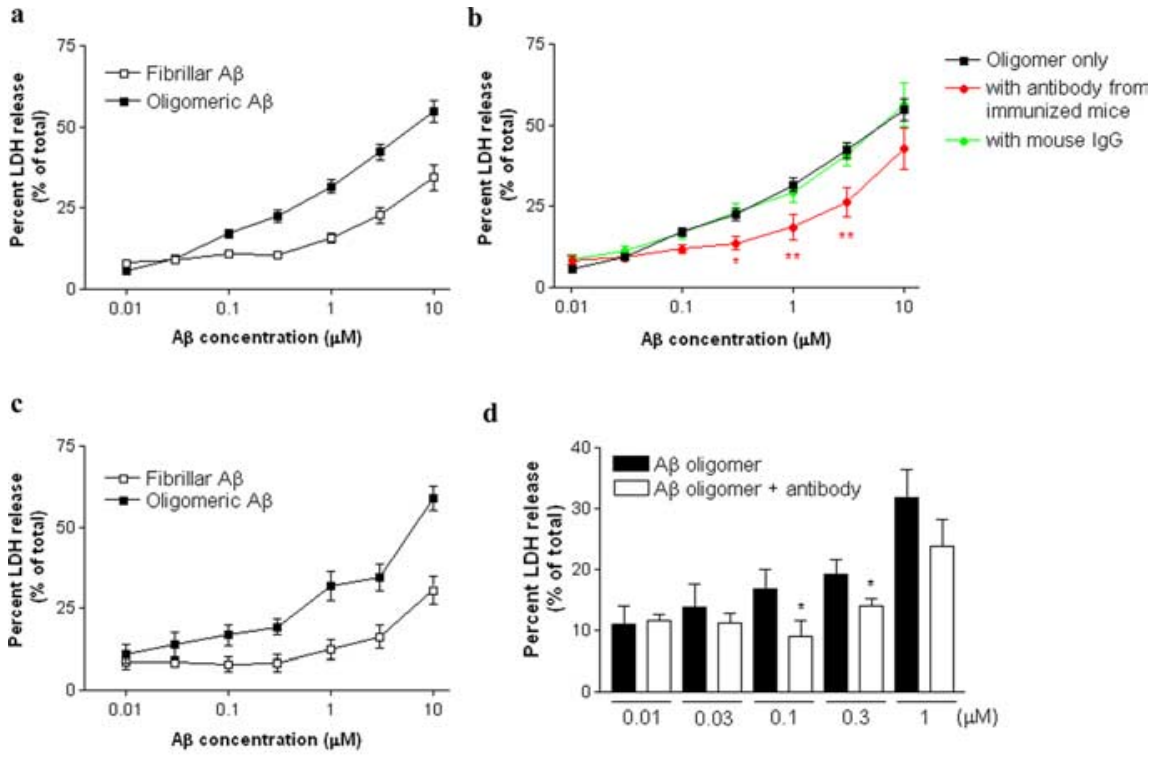

d

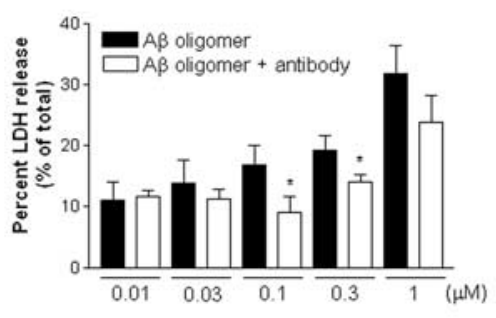

e

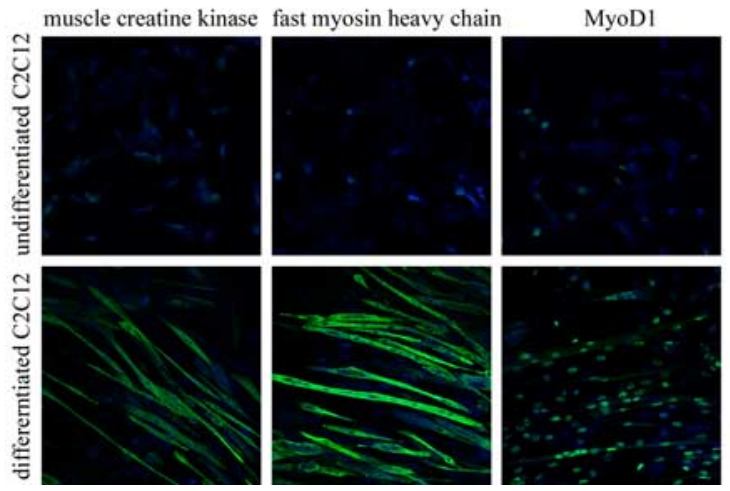

Figure 6. Cytotoxicity of $A \beta$ oligomers in C2C12 myoblast cells is neutralized by anti-A $\beta$ antibodies generated in the immunized mice. $\boldsymbol{a}$, Undifferentiated C2C12 cells were exposed to oligomeric or fibrillar A $\beta(0.01-10 \mu \mathrm{m})$ for $24 \mathrm{~h}$, and cytotoxicity was quantitatively measured by LDH assay. Data represent mean \pm SEM of five separate experiments in at least triplicate $(n=15) \cdot \boldsymbol{b}$, The protective effect of anti-A $\beta$ antibodies on oligomer toxicity was determined in C2C12 cells. Affinity purified antibody from immunized mice or preimmune mouse $\operatorname{lgG}(30 \mu \mathrm{g} / \mathrm{ml})$ was coadministered with $A \beta$ oligomers $(0.01-3 \mu \mathrm{m})$ for $24 \mathrm{~h}$, and cytotoxicity was measured by LDH assay. ${ }^{* *} p<0.01$ compared with cells exposed to oligomer only. Data represent mean $\pm \mathrm{SEM}$ of four separate experiments in triplicates $(n=12)$. c, Similarly, cytotoxicity of oligomeric and fibrillar $A \beta$ on differentiated $C 2 C 12$ cells was determined. $\boldsymbol{d}$, Toxicity of oligomeric $A \beta$ on differentiated $C 2 C 12$ cells was significantly attenuated by anti- $A \beta$ antibody 20.1. $p<0.05$ compared with $A \beta$ oligomer only. $\boldsymbol{e}$, Differentiation of $\mathrm{C} 2 \mathrm{C} 12$ cells was confirmed by the expression of muscle creatine kinase, myosin heavy chain or MyoD1 (green) with nuclear counter staining (blue).

studies have shown that these amino acids in the human peptide are particularly important for controlling the aggregation property of $\mathrm{A} \beta$ and are presumed to have toxic properties (Fraser et al., 1992; Dyrks et al., 1993; Otvos et al., 1993; Atwood et al., 1998).

The anti-A $\beta$ antibodies induced in the $M C K-A P P / P S 1$ transgenic mice by active immunization effectively removed various assembly states of $\mathrm{A} \beta$ including fibrils and oligomers. Further experiments will be required to determine the exact mechanism(s) by which the antibodies facilitate clearance of intracellu$\operatorname{lar} \mathrm{A} \beta$. However, several studies have demonstrated that intracellular deposits of A $\beta$ or $\alpha$-synuclein can be cleared from neurons after immunization (Oddo et al., 2004; Billings et al., 2005; Masliah et al., 2005).

In the case of active immunization against $\mathrm{A} \beta$ in $\mathrm{AD}$, the remarkable successes in animal models, mostly free of adverse events, did not translate to the clinical trial in $\mathrm{AD}$ patients, because $\sim 6 \%$ of the patients developed meningoencephalitis
(Schenk et al., 2005). Currently, more than 10 new approaches to active and passive immunotherapy are in various stages of clinical trials with the goal of improving the safety and efficacy of anti-A $\beta$ immunotherapy approaches (Wisniewski and Konietzko, 2008). As a consequence of this continued improvement in anti-A $\beta$ therapeutic strategies, there may be real opportunities to safely pursue a clinical trial in IBM patients.

The progression of skeletal muscle weakness and atrophy in IBM is relatively slow but irreversible. Ultimately, patients are forced to rely on assisting devices and/or caregivers. Currently, no effective treatment for IBM exists; a number of immunosuppressive or immunomodulatory therapies that have worked well on other inflammatory myopathies have shown only marginal improvements in IBM patients (Walter et al., 2000; Dalakas et al., 2001; Badrising et al., 2002; Rutkove et al., 2002; Tawil, 2004). Hence, there is a critical need to develop novel approaches to treating IBM. In this study, we provide evidence that $A \beta$ is one of the key pathological components of IBM and promoting clearance of $\mathrm{A} \beta$ from skeletal muscle may be a valid therapeutic strategy to pursue. Additional studies using different animal models would further advance the understanding of this devastating age-associated myopathy.

\section{References}

Askanas V, Engel WK (2005) Molecular pathology and pathogenesis of inclusion-body myositis. Microsc Res Tech 67:114-120.

Askanas V, Engel WK (2008) Inclusion-body myositis: muscle-fiber molecular pathology and possible pathogenic significance of its similarity to Alzheimer's and Parkinson's disease brains. Acta Neuropathol 116:583-595.

Askanas V, Serdaroglu P, Engel WK, Alvarez RB (1991) Immunolocalization of ubiquitin in muscle biopsies of patients with inclusion body myositis and oculopharyngeal muscular dystrophy. Neurosci Lett 130:73-76.

Askanas V, Alvarez RB, Engel WK (1993) beta-Amyloid precursor epitopes in muscle fibers of inclusion body myositis. Ann Neurol 34:551-560.

Askanas V, Engel WK, Bilak M, Alvarez RB, Selkoe DJ (1994) Twisted tubulofilaments of inclusion body myositis muscle resemble paired helical filaments of Alzheimer brain and contain hyperphosphorylated tau. Am J Pathol 144:177-187.

Atwood CS, Moir RD, Huang X, Scarpa RC, Bacarra NM, Romano DM, Hartshorn MA, Tanzi RE, Bush AI (1998) Dramatic aggregation of Alzheimer abeta by $\mathrm{Cu}(\mathrm{II})$ is induced by conditions representing physiological acidosis. J Biol Chem 273:12817-12826.

Badrising UA, Maat-Schieman ML, Ferrari MD, Zwinderman AH, Wessels JA, Breedveld FC, van Doorn PA, van Engelen BG, Hoogendijk JE, Höweler CJ, de Jager AE, Jennekens FG, Koehler PJ, de Visser M, Viddeleer A, Verschuuren JJ, Wintzen AR (2002) Comparison of weakness progression in inclusion body myositis during treatment with methotrexate or placebo. Ann Neurol 51:369-372.

Banwell BL, Engel AG (2000) AlphaB-crystallin immunolocalization yields new insights into inclusion body myositis. Neurology 54:1033-1041. 
Billings LM, Oddo S, Green KN, McGaugh JL, LaFerla FM (2005) Intraneuronal Abeta causes the onset of early Alzheimer's disease-related cognitive deficits in transgenic mice. Neuron 45:675-688.

Boehm SL 2nd, Crabbe JC, Phillips TJ (2000) Sensitivity to ethanol-induced motor incoordination in FAST and SLOW selectively bred mice. Pharmacol Biochem Behav 66:241-247.

Caughey B, Lansbury PT (2003) Protofibrils, pores, fibrils, and neurodegeneration: separating the responsible protein aggregates from the innocent bystanders. Annu Rev Neurosci 26:267-298.

Cribbs DH, Ghochikyan A, Vasilevko V, Tran M, Petrushina I, Sadzikava N, Babikyan D, Kesslak P, Kieber-Emmons T, Cotman CW, Agadjanyan MG (2003) Adjuvant-dependent modulation of Th1 and Th2 responses to immunization with beta-amyloid. Int Immunol 15:505-514.

Dalakas MC (2006a) Inflammatory, immune, and viral aspects of inclusionbody myositis. Neurology 66:S33-38.

Dalakas MC (2006b) Sporadic inclusion body myositis-diagnosis, pathogenesis and therapeutic strategies. Nat Clin Pract Neurol 2:437-447.

Dalakas MC, Koffman B, Fujii M, Spector S, Sivakumar K, Cupler E (2001) A controlled study of intravenous immunoglobulin combined with prednisone in the treatment of IBM. Neurology 56:323-327.

DeMattos RB, Bales KR, Cummins DJ, Dodart JC, Paul SM, Holtzman DM (2001) Peripheral anti-A beta antibody alters CNS and plasma A beta clearance and decreases brain A beta burden in a mouse model of Alzheimer's disease. Proc Natl Acad Sci U S A 98:8850-8855.

Demuro A, Mina E, Kayed R, Milton SC, Parker I, Glabe CG (2005) Calcium dysregulation and membrane disruption as a ubiquitous neurotoxic mechanism of soluble amyloid oligomers. J Biol Chem 280:17294-17300.

Dyrks T, Dyrks E, Masters CL, Beyreuther K (1993) Amyloidogenicity of rodent and human beta A4 sequences. FEBS Lett 324:231-236.

Eisenberg I, Avidan N, Potikha T, Hochner H, Chen M, Olender T, Barash M, Shemesh M, Sadeh M, Grabov-Nardini G, Shmilevich I, Friedmann A, Karpati G, Bradley WG, Baumbach L, Lancet D, Asher EB, Beckmann JS, Argov Z, Mitrani-Rosenbaum S (2001) The UDP-N-acetylglucosamine 2-epimerase/ $\mathrm{N}$-acetylmannosamine kinase gene is mutated in recessive hereditary inclusion body myopathy. Nat Genet 29:83-87.

Ferrer I, Martín B, Castaño JG, Lucas JJ, Moreno D, Olivé M (2004) Proteasomal expression, induction of immunoproteasome subunits, and local MHC class I presentation in myofibrillar myopathy and inclusion body myositis. J Neuropathol Exp Neurol 63:484-498.

Fidziañska A, Glinka Z (2006) Rimmed vacuoles with beta-amyloid and tau protein deposits in the muscle of children with hereditary myopathy. Acta Neuropathol 112:185-193.

Fraser PE, Nguyen JT, Inouye H, Surewicz WK, Selkoe DJ, Podlisny MB, Kirschner DA (1992) Fibril formation by primate, rodent, and Dutchhemorrhagic analogues of Alzheimer amyloid beta-protein. Biochemistry 31:10716-10723.

Frenkel D, Maron R, Burt DS, Weiner HL (2005) Nasal vaccination with a proteosome-based adjuvant and glatiramer acetate clears beta-amyloid in a mouse model of Alzheimer disease. J Clin Invest 115:2423-2433.

Fukuchi K, Pham D, Hart M, Li L, Lindsey JR (1998) Amyloid-beta deposition in skeletal muscle of transgenic mice: possible model of inclusion body myopathy. Am J Pathol 153:1687-1693.

Gong Y, Chang L, Viola KL, Lacor PN, Lambert MP, Finch CE, Krafft GA, Klein WL (2003) Alzheimer's disease-affected brain: presence of oligomeric A beta ligands (ADDLs) suggests a molecular basis for reversible memory loss. Proc Natl Acad Sci U S A 100:10417-10422.

Gustavsson S, Hjulström-Chomez S, Lidström BM, Ahlborg N, Andersson R, Heyman B (1998) Impaired antibody responses in H-2Ab mice. J Immunol 161:1765-1771.

Jin LW, Hearn MG, Ogburn CE, Dang N, Nochlin D, Ladiges WC, Martin GM (1998) Transgenic mice over-expressing the C-99 fragment of betaPP with an alpha-secretase site mutation develop a myopathy similar to human inclusion body myositis. Am J Pathol 153:1679-1686.

Kayashima T, Matsuo H, Satoh A, Ohta T, Yoshiura K, Matsumoto N, Nakane Y, Niikawa N, Kishino T (2002) Nonaka myopathy is caused by mutations in the UDP-N-acetylglucosamine-2-epimerase/Nacetylmannosamine kinase gene (GNE). J Hum Genet 47:77-79.

Kayed R, Head E, Thompson JL, McIntire TM, Milton SC, Cotman CW, Glabe CG (2003) Common structure of soluble amyloid oligomers implies common mechanism of pathogenesis. Science 300:486-489.

Kayed R, Head E, Sarsoza F, Saing T, Cotman CW, Necula M, Margol L, Wu J, Breydo L, Thompson JL, Rasool S, Gurlo T, Butler P, Glabe CG (2007)
Fibril specific, conformation dependent antibodies recognize a generic epitope common to amyloid fibrils and fibrillar oligomers that is absent in prefibrillar oligomers. Mol Neurodegener 2:18.

Kitazawa M, Green KN, Caccamo A, LaFerla FM (2006) Genetically augmenting Abeta42 levels in skeletal muscle exacerbates inclusion body myositis-like pathology and motor deficits in transgenic mice. Am J Pathol 168:1986-1997.

Kitazawa M, Trinh DN, LaFerla FM (2008) Inflammation induces tau pathology in inclusion body myositis model via glycogen synthase kinase3beta. Ann Neurol 64:15-24.

Lesné S, Koh MT, Kotilinek L, Kayed R, Glabe CG, Yang A, Gallagher M, Ashe $\mathrm{KH}$ (2006) A specific amyloid-beta protein assembly in the brain impairs memory. Nature 440:352-357.

Malaplate-Armand C, Florent-Béchard S, Youssef I, Koziel V, Sponne I, Kriem B, Leininger-Muller B, Olivier JL, Oster T, Pillot T (2006) Soluble oligomers of amyloid-beta peptide induce neuronal apoptosis by activating a cPLA2-dependent sphingomyelinase-ceramide pathway. Neurobiol Dis 23:178-189.

Malicdan MC, Noguchi S, Nonaka I, Hayashi YK, Nishino I (2007) A Gne knockout mouse expressing human GNE D176V mutation develops features similar to distal myopathy with rimmed vacuoles or hereditary inclusion body myopathy. Hum Mol Genet 16:2669-2682.

Martinsson T, Oldfors A, Darin N, Berg K, Tajsharghi H, Kyllerman M, Wahlstrom J (2000) Autosomal dominant myopathy: missense mutation (Glu-706 -> Lys) in the myosin heavy chain IIa gene. Proc Natl Acad Sci U S A 97:14614-14619.

Masliah E, Rockenstein E, Adame A, Alford M, Crews L, Hashimoto M, Seubert P, Lee M, Goldstein J, Chilcote T, Games D, Schenk D (2005) Effects of alpha-synuclein immunization in a mouse model of Parkinson's disease. Neuron 46:857-868.

McFerrin J, Engel WK, Askanas V (1998) Impaired innervation of cultured human muscle overexpressing betaAPP experimentally and genetically: relevance to inclusion-body myopathies. Neuroreport 9:3201-3205.

Mills CD, Kincaid K, Alt JM, Heilman MJ, Hill AM (2000) M-1/M-2 macrophages and the Th1/Th2 paradigm. J Immunol 164:6166-6173.

Monsonego A, Imitola J, Petrovic S, Zota V, Nemirovsky A, Baron R, Fisher Y, Owens T, Weiner HL (2006) Abeta-induced meningoencephalitis is IFN-gamma-dependent and is associated with T cell-dependent clearance of Abeta in a mouse model of Alzheimer's disease. Proc Natl Acad Sci U S A 103:5048-5053.

Moussa CE, Fu Q, Kumar P, Shtifman A, Lopez JR, Allen PD, LaFerla F, Weinberg D, Magrane J, Aprahamian T, Walsh K, Rosen KM, Querfurth HW (2006) Transgenic expression of beta-APP in fast-twitch skeletal muscle leads to calcium dyshomeostasis and IBM-like pathology. FASEB J 20:2165-2167.

Needham M, Mastaglia FL (2008) Sporadic inclusion body myositis: a continuing puzzle. Neuromuscul Disord 18:6-16.

Oddo S, Billings L, Kesslak JP, Cribbs DH, LaFerla FM (2004) Abeta immunotherapy leads to clearance of early, but not late, hyperphosphorylated tau aggregates via the proteasome. Neuron 43:321-332.

Oddo S, Caccamo A, Tran L, Lambert MP, Glabe CG, Klein WL, LaFerla FM (2006a) Temporal profile of amyloid-beta (Abeta) oligomerization in an in vivo model of Alzheimer disease. A link between Abeta and tau pathology. J Biol Chem 281:1599-1604.

Oddo S, Vasilevko V, Caccamo A, Kitazawa M, Cribbs DH, LaFerla FM (2006b) Reduction of soluble Abeta and tau, but not soluble Abeta alone, ameliorates cognitive decline in transgenic mice with plaques and tangles. J Biol Chem 281:39413-39423.

Otvos L Jr, Szendrei GI, Lee VM, Mantsch HH (1993) Human and rodent Alzheimer beta-amyloid peptides acquire distinct conformations in membrane-mimicking solvents. Eur J Biochem 211:249-257.

Querfurth HW, Suhara T, Rosen KM, McPhie DL, Fujio Y, Tejada G, Neve RL, Adelman LS, Walsh K (2001) Beta-amyloid peptide expression is sufficient for myotube death: implications for human inclusion body myopathy. Mol Cell Neurosci 17:793-810.

Reiner SL, Locksley RM (1995) The regulation of immunity to Leishmania major. Annu Rev Immunol 13:151-177.

Rustay NR, Wahlsten D, Crabbe JC (2003) Assessment of genetic susceptibility to ethanol intoxication in mice. Proc Natl Acad Sci U S A 100:2917-2922.

Rutkove SB, Parker RA, Nardin RA, Connolly CE, Felice KJ, Raynor EM 
(2002) A pilot randomized trial of oxandrolone in inclusion body myositis. Neurology 58:1081-1087.

Sarkozi E, Askanas V, Johnson SA, Engel WK, Alvarez RB (1993) betaAmyloid precursor protein mRNA is increased in inclusion-body myositis muscle. Neuroreport 4:815-818.

Schenk DB, Seubert P, Grundman M, Black R (2005) A beta immunotherapy: Lessons learned for potential treatment of Alzheimer's disease. Neurodegener Dis 2:255-260.

Schmidt J, Barthel K, Wrede A, Salajegheh M, Bähr M, Dalakas MC (2008) Interrelation of inflammation and APP in SIBM: IL-1\{beta\} induces accumulation of \{beta\}-amyloid in skeletal muscle. Brain 131:1228-1240.

Sugarman MC, Yamasaki TR, Oddo S, Echegoyen JC, Murphy MP, Golde TE, Jannatipour M, Leissring MA, LaFerla FM (2002) Inclusion body myositis-like phenotype induced by transgenic overexpression of beta APP in skeletal muscle. Proc Natl Acad Sci U S A 99:6334-6339.

Tawil R (2004) Randomized pilot trial of high-dose betaINF-1a in patients with inclusion body myositis. Neurology 63:718-720.

Vattemi G, Engel WK, McFerrin J, Askanas V (2003) Cystatin C colocalizes with amyloid-beta and coimmunoprecipitates with amyloid-beta precursor protein in sporadic inclusion-body myositis muscles. J Neurochem 85:1539-1546.

Walsh DM, Klyubin I, Fadeeva JV, Rowan MJ, Selkoe DJ (2002a) Amyloid- beta oligomers: their production, toxicity and therapeutic inhibition. Biochem Soc Trans 30:552-557.

Walsh DM, Klyubin I, Fadeeva JV, Cullen WK, Anwyl R, Wolfe MS, Rowan MJ, Selkoe DJ (2002b) Naturally secreted oligomers of amyloid beta protein potently inhibit hippocampal long-term potentiation in vivo. $\mathrm{Na}$ ture 416:535-539.

Walter MC, Lochmüller H, Toepfer M, Schlotter B, Reilich P, Schröder M, Müller-Felber W, Pongratz D (2000) High-dose immunoglobulin therapy in sporadic inclusion body myositis: a double-blind, placebocontrolled study. J Neurol 247:22-28.

Watts GD, Wymer J, Kovach MJ, Mehta SG, Mumm S, Darvish D, Pestronk A, Whyte MP, Kimonis VE (2004) Inclusion body myopathy associated with Paget disease of bone and frontotemporal dementia is caused by mutant valosin-containing protein. Nat Genet 36:377-381.

Weihl CC, Miller SE, Hanson PI, Pestronk A (2007) Transgenic expression of inclusion body myopathy associated mutant $\mathrm{p} 97 / \mathrm{VCP}$ causes weakness and ubiquitinated protein inclusions in mice. Hum Mol Genet 16:919-928.

Wisniewski T, Konietzko U (2008) Amyloid-beta immunisation for Alzheimer's disease. Lancet Neurol 7:805-811.

Wojcik S, Engel WK, McFerrin J, Paciello O, Askanas V (2006) AbetaPPoverexpression and proteasome inhibition increase alphaB-crystallin in cultured human muscle: relevance to inclusion-body myositis. Neuromuscul Disord 16:839-844. 